Journal of Tourism Theory and Research

Online, http://dergipark.gov.tr/jttr

Volume: 4(2), 2018

\title{
An e-loyalty model proposal for online travel reservation websites
}

\section{Duygu Tunal1 ${ }^{1}$ Ahmet Aytekin ${ }^{2}$}

\begin{abstract}
Online travel reservation websites need e-loyal customers to be able to drive their profitability and existence. In this context, the aim of this study is to propose an e-loyalty model for travel reservation websites in the business to consumer (B2C) concept. The study brought together important concepts thought to be related to e-loyalty, such as system quality, trust, satisfaction, alternative attractiveness, word of mouth, and repurchase intention. As a result, it was determined that system quality, trust, satisfaction and word of mouth have a positive effect on e-loyalty, unlike alternative attractiveness which has a negative effect. It was also determined that e-loyalty has a positive effect on repurchase intention.
\end{abstract}

Keywords: Online travel reservation websites; E-commerce; E-loyalty; Structural equation modelling

To cite this article: Tunal1, D., Aytekin, A. (2018). An e-loyalty model proposal for online travel reservation websites. Journal of Tourism Theory and Research, 4(2), 98-110. DOI: 10.24288/jttr.420439

${ }^{1} \mathrm{PhD}$, Anadolu University, Eskişehir, Turkey, dcoskun@anadolu.edu.tr

${ }^{2}$ Research Assistant, Anadolu University, Eskişehir, Turkey, ahmetaytekin@anadolu.edu.tr 


\section{Introduction}

The Internet has led to great changes in every aspect of our lives. Trade has changed in this context, and the concept of e-commerce has emerged. E-commerce is defined as the use of the Internet to facilitate, conduct and handle trading operations (DeLone and McLean, 2004). In 2016, the volume of retail e-commerce in the world grew by $17.5 \%$, and reached 2,671 trillion dollars (Ecommerce Foundation, 2016). This shows how important it is for businesses to create websites and transfer their trading activities to the Internet. Also, the tourism sector is one of the areas in which ecommerce develops. The pervasive shift of travel sales to the Internet has caused a gradual loss of relevance and importance of the traditional travel agencies. However, traditional travel agents who envisaged such changes moved their services to the digital environment and took their positions in this new market of online travel reservations. Other online intermediaries that facilitate the sale of the products of businesses that provide both accommodation and other tourist services also emerged in this wave. Another important point is that individual customers can create their own holiday package with the innovations brought by the Internet (Werthner and Ricci, 2007).

While the share of e-commerce institutions responding to these developments in travel reservations is constantly increasing, the entry of new players into the market is inevitable. This brings with it the issue of customer retention and sustainability policies. These policies focus on the customers, naturally the most important component of any business. Many concepts, such as loyalty, trust, satisfaction, have been used to explain the sustainable transaction relationship of an enterprise with its customers. Loyalty is one of the main concepts in marketing, especially in customer retention (Ribbink et al., 2004; Toufaily et al., 2013). For e-commerce businesses, e-loyalty is used as the operative term instead of loyalty. Flavian et al. (2006) defines eloyalty as a customer's intention to continue making purchases from a particular e-commerce website and not move to another website. In other words, e-loyalty is a positive attitude that causes the customer to make repeat transactions with an e-commerce enterprise (Anderson and Srinivasan, 2003).
E-loyalty may be attributed to several factors, such as e-trust, e-quality, e-service, perceived value, website organization, system quality, and the existence of alternatives. Gommans, Krishnan, and Scheffold (2001) stated that, with the rapid growth of ecommerce and online consumer shopping trends, the creation and maintenance of customer loyalty in electronic markets have become important in marketing theory and practice.

In 2015 , the number of e-commerce websites in Turkey decreased compared to the previous year, but the market grew from a monetary point of view. On the other hand, vacation and travel expenditures are the largest expenditure item in e-commerce market 1 . As a result, increasing the number of new customers and retaining the current customers have become prominent issues for travel reservation websites. Griffin and Herres (2002) found that an increase in the customer retention rate by $5 \%$ may effect a change in the companies' profits to the tune of between $25 \%$ and $85 \%$. This study aims to propose an effective e-loyalty model, which is the most important instrument of travel reservation websites, using alternative modelling strategy. Moreover, as latent variables, system quality, trust, satisfaction, alternative attractiveness, word of mouth, and the repurchase intention were proposed together for the first time in an e-loyalty model. Apart from these, researchers to work on this subject can expand this base model according to the technological, legal or environmental changes.

\section{Literature}

E-loyalty is a customer's positive attitude towards an e-commerce website, and his/her desire to maintain this relationship. In studies on e-loyalty, the basic antecedents considered to this concept are satisfaction, trust, service quality and perceived value. Apart from these, e-loyalty has been associated with many other antecedents and consequences (Valvi and Fragkos, 2012). The diversity of e-loyalty models stands out in literature. Toufaily et al. (2013) stated that determinants of e-loyalty in these models are customer attributes (satisfaction, trust, perceived value, motivation, information technology knowledge), product/service attributes (product quality, service quality, price sense), operating attributes (online sales strategy, competitiveness, information technology 
policies), website attributes (system-service quality, accessibility / credibility, sales effectiveness, security, download speed, etc), and environmental attributes. These are all antecedents of e-loyalty. Toufaily et al. (2013) noted the lack of sufficient attention on the relationship between e-loyalty and its consequences such as repurchase, more payment, price sensitivity.

One of these important loyalty models is Information System (IS) Success Model. It was developed by DeLone and McLean (1992) to ensure that businesses can measure their investment in information technologies and e-commerce investment. They stated that the economic laws have not been rewritten, the basic business principles are still valid. The long-term success of the companies continues to be related to achieving their positive net income. IS Success Model was revised by DeLone and McLean in 2004 to include system quality, information quality, service quality, usability, user satisfaction and net profit sizes. In another study based on this model, Chen, Yen, Pornpriphet, and Widjaja (2015) used the perceived value as exogenous variable and trust and satisfaction as mediator variables. The study was conducted on e-commerce users in Taiwan and Thailand, with the aim of revealing cultural differences. In the tourism setting, Huang (2008) aimed to propose an e-loyalty model for business to business (B2B) travel agencies. In this model, quality and trust explain e-loyalty, and e-loyalty was used as an intermediary variable between these two variables and purchase intention.

Figure 1. Conceptual e-loyalty model for travel reservation websites

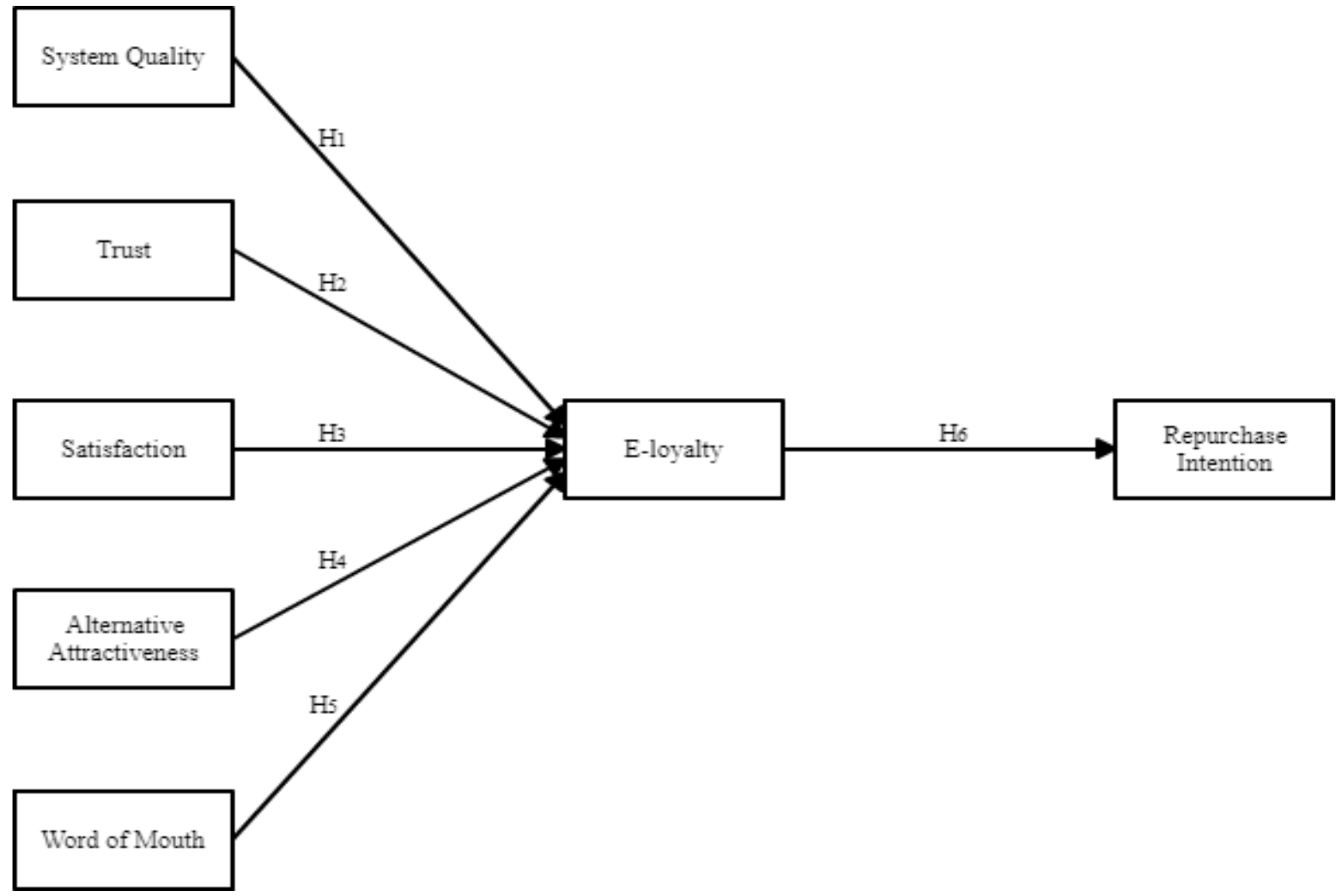

This study aims to present a new e-loyalty model for B2C travel reservation websites, based on the three models (Chen et al., 2015; DeLone and McLean,2004; Huang, 2008). Because travel reservation websites sell services, they differ from e-commerce websites that sell goods or products. The assessment should be made according to travel reservation websites. In other words, e-loyalty for travel reservation websites should be expected to be related to different factors. The structures used in this study were determined within this scope. Srinivasan, Anderson, and Ponnavolu (2002) reported that e-loyalty is related to word of mouth and search for alternatives. For this reason, the study investigated the relationship between e-loyalty and word of mouth, alternative attractiveness, satisfaction, system quality and trust (Chen et al., 2015; DeLone and McLean, 2004; Srinivasan et al., 2002; $\mathrm{Wu}, 2011)$. E-loyalty was also found to have more 
influence on the customer repurchase intention than price (Huang, 2008; Reichheld and Schefter, 2000). In this regard, we also sought to examine whether repurchase intention (Eggert and Ulaga, 2002), which is among the consequences of e-loyalty, will improve as a result of e-loyalty. Moreover, the great majority of the studies in literature are concentrated on satisfaction and loyalty, but the number of studies that examine the satisfaction - loyalty - repurchase relationship is rather limited. However, the continuous purchase by customer from the same website in the future depends on the relationship of these basic dimensions (Curtis et al., 2011). Within this framework, the hypothetical model of the research is presented in Fig. 1.

An alternative model strategy has also been employed in the study. The main objective of this strategy is to determine which of the alternative models is most supported by the data to explain the relationships between the variables studied. It is possible that more than one model can give valid results at the same level while trying to explain the relations between the variables determined in the study (Şimşek, 2007). In this way, alternative models that can be created with the variables will be evaluated and possible different valid models, appropriate for data and literature, discussed. Hypotheses related to the research model proposed in the study are presented below.

\section{System quality and e-loyalty}

It can be difficult to measure the quality of information technologies used by businesses at a time when the effects of the Internet and information technologies on businesses are continuously increasing. IS Success Model developed by DeLone and McLean earned its place in the literature (DeLone and McLean, 1992; 2004) for this purpose. System quality, which is one of the important components of this model, means that the customer can easily navigate through the website with successful interaction with the interface. A good website interface is expected to facilitate customer experience on the website and increase the likelihood of making a purchase (Kuan et al., 2005). Chen et al. (2015) found the system quality to have a positive effect on e-loyalty. Accordingly, our hypothesis is that there is a relationship between system quality and e-loyalty;

H1: System quality positively affects e-loyalty

\section{Trust and e-loyalty}

Trust in the context of e-commerce can be defined as the degree of confidence that customers have in their transactions (Ribbink et al., 2004). Reichheld and Schefter (2000) stated trust is the main factor in acquiring loyalty. Ribbink et al. (2004) stated that even though trust increased loyalty, it had not received enough attention in the literature. They proposed a model in which trust has a central role. In that model, they found that trust has a direct effect on loyalty, and service quality influences loyalty through satisfaction and trust. Huang (2008) pointed out that e-quality and trust are the antecedents of e-loyalty for travel agencies, and that loyalty increases the repurchase intention. Anderson and Srinivasan (2003) noted that trust and perceived value increase e-loyalty and satisfaction in terms of business. Nusair and Nua (2010) stated that trust is positively related to affective loyalty, and that customer satisfaction gained through a relationship with the website will increase customer's loyalty.

Kim, Jin, and Swinney (2009) established that eloyalty is influenced by satisfaction and trust, and that trust and satisfaction are significantly related to each other. They also reported that the dimensions of etail quality have different effects on satisfaction and trust. Floh and Treiblmaier (2006) stated that satisfaction and trust are important predictors of loyalty. We there established the following in respect of these findings in literature;

H2: Trust positively affects e-loyalty.

\section{Satisfaction and e-loyalty}

Customers have feelings when shopping at any store in anticipation of their expectations. For online travel reservation websites, satisfaction is the degree to which the expectations of the customers are met. The relationship between loyalty and satisfaction has been intensively researched in the literature. Oliver (1999) stated that satisfaction and loyalty are indissociably and asymmetrically related to each other. The majority of the studies reveal that there is a meaningful relationship between these two dimensions. In one of these studies, Balabanis, Reynolds, and Simintiras (2006) stated that customers do not feel attached to estore unless they are greatly satisfied. Likewise, Anderson and Srinivasan (2003), Chang and Chen 
(2009), Floh and Treiblmaier (2006), Kim, Jin and Swinney (2009), and Koh, Hur, and Valacich (2011) have reached a conclusion that loyalty is positively affected by satisfaction. The following hypotheses is proposed in this context;

H3: Satisfaction positively affects e-loyalty.

\section{Alternative attractiveness and e-loyalty}

Alternative attractiveness can be defined as the customer's prediction of the likelihood that her/his expectations will be met at another company (Ping, 1993; Wu,2011). When the customer does not get his money's worth, he is looking for alternatives, and this situation reduces his loyalty (Valvi and Fragkos, 2012). Rusbult (1980) stated that having the best alternate or increasing the value of the alternatives would increase the loyalty. $\mathrm{Wu}$ (2011) noted that the negative mediation role of the zone of tolerance between satisfaction and e-loyalty, and the positive mediating role of the zone of tolerance between inertia and e-loyalty decreased as alternative attractiveness increased. Srinivasan et al. (2002) expressed that customer e-loyalty is negatively associated with the search for alternatives. In this context, the following hypothesis was proposed;

H4: Alternative attractiveness negatively affects eloyalty.

\section{Word of mouth and e-loyalty}

As social entities, people share their experiences within social networks. In this context, word of mouth can be defined as written or verbal acts which occur when customers communicate their experiences before, during and after a purchase. Word of mouth should be expected to affect e-loyalty within this scope (Litvin et al., 2008). It is even possible that word of mouth is more effective than advertising, e-mail messages and many marketing techniques in, providing affective e-loyalty (Xiaojuan $\mathrm{Ou}$ and Ling Sia, 2003). Srinivasan et al. (2002) indicated that word of mouth has a positive effect on e-loyalty. The following hypothesis was proposed in this regard;

H5: Word of mouth positively affects e-loyalty.

\section{E-loyalty and repurchase intention}

Repurchase intention is the decision to make a return purchase of goods or services from the same institution, taking into account possible circumstances
(Hellier et al., 2003). Valvi and Fragkos (2012) summarized the literature on studies on e-commerce regulations. They found that e-loyalty was considered in these studies as a factor before, during and after sales. Repurchase intention was considered a significant consequence of e-loyalty. Reichheld and Schefter (2000) predicated that it would be wrong for an enterprise to think that it could attract an ecommerce customer just by reducing its goods or services' prices, and that loyalty is more effective than the price in this regard. Huang (2008) noted that loyalty led to increased repurchase intentions. Curtis et al. (2011) also noted that e-loyalty had an impact on repurchase intention. The following hypothesis is presented in light of these discussions.

H6: E-loyalty positively affects the repurchase intention.

\section{Methodology}

The study examined the e-loyalty of customers who bought products from travel reservation websites. It is impossible to reach the entire population due to the fact that there are many companies operating in the online travel reservation sector and the number of customers who shop on these platforms may not be easily determined. For this reason, the researchers decided to make the study on target population. The academicians, who travel frequently, were designated as the target group to represent this customer group. Questionnaire was generated by the authors in view of the literature and presented to the Ethics Committee of Anadolu University. The Committee approved the survey on the condition that it would be applied voluntarily to participants. Then, the authors sought permission from Anadolu University and Osmangazi University about implementation of the survey among academicians. Upon being granted permission by the institutions, 4184 academicians working in the province of Eskişehir were reached via institutional email on April-May 2017. The participants were provided with a link in the email from which they could access the questionnaire. They were made aware of their voluntary participation and their ability to quit the study whenever they wanted. Although this reduces participation, it is believed that the survey's credibility has increased (Akbulut, 2014). In addition, this application also prevents the accidental participation of individuals who are not familiar with electronic media. 
The survey questions were divided into two sections; demographic and e-loyalty model questions. 293 participants filled out the survey. This sample size is adequate for analysis according to the sample size of at least 200 for normal distributed data or 265 for nonnormal distributed data (Muthén and Muthén 2002). SPSS 23.0 and LISREL 8.80 software were used in the analysis carried out in the study. The demographic characteristics of the participants are presented in Table 1 .

The reason for missing data in some demographic variables in Table 1 is because response to these questions was optional for participants. The fact that responding to these questions was not compulsory to continue to fill out the form was important to avoid the feeling of pressure. Demographic results indicate that most of the participants were under the age of 40 $(69.5 \%)$, took domestic travel $(63.7 \%)$, were married $(64.6 \%)$ had the title of research assistant $(\% 45)$ and preferred booking.com (\%62.5), which is an international travel reservation website.

Table 1. Demographic characteristics of respondents

\begin{tabular}{|c|c|c|c|}
\hline Variable & Category & $\mathrm{n}$ & $\%$ \\
\hline \multirow{6}{*}{ Age } & $23-30$ & 92 & 33,8 \\
\hline & $31-40$ & 97 & 35,7 \\
\hline & $41-50$ & 53 & 19,5 \\
\hline & $51-60$ & 21 & 7,7 \\
\hline & $61+$ & 9 & 3,3 \\
\hline & Total & 272 & 100 \\
\hline \multirow{3}{*}{ Marital Status } & Married & 188 & 64,6 \\
\hline & Single & 103 & 35,4 \\
\hline & Total & 291 & 100 \\
\hline \multirow{6}{*}{ Title } & Research Assistant & 131 & 45,0 \\
\hline & Lecturer & 67 & 23,0 \\
\hline & Lecturer, $\mathrm{PhD}$ & 52 & 17,9 \\
\hline & Associate Professor & 20 & 6,9 \\
\hline & Professor & 21 & 7,2 \\
\hline & Total & 291 & 100 \\
\hline \multirow{8}{*}{$\begin{array}{l}\text { Travel } \\
\text { Preference }\end{array}$} & Domestic & 184 & 63,7 \\
\hline & Foreign & 105 & 36,3 \\
\hline & Total & 289 & 100 \\
\hline & Booking.com & 183 & 62,5 \\
\hline & Etstur.com & 42 & 14,3 \\
\hline & Tatilsepeti.com & 21 & 7,2 \\
\hline & Others & 47 & 16,0 \\
\hline & Total & 293 & 100,0 \\
\hline
\end{tabular}

Copyright (C) 2015 by JTTR
In the study, the relationship among word of mouth (Srinivasan et al., 2002), alternative attractiveness (Wu, 2011), satisfaction (Chen et al., 2015), system quality (Chen et al., 2015; DeLone and McLean, 2004), trust (Chen et al., 2015) with e-loyalty (Srinivasan et al., 2002) was examined with a structural equation model (SEM).

\section{Results}

SEM was preferred in this study, because it allows for the creation of more complex models than regression analysis or general linear models (GLM). Also, it provides observation of measurement errors, modification suggestions due to softwares such as LISREL, and indirect and direct relationships can be taken into consideration at the same time. SEM consists of measurement model and structural model. In addition to the hypothetical research model, alternative models that can be formed with the variables were also examined.

\section{Measurement model}

The relationship between observed variables and latent variables is examined using a measurement model. It was purposed to obtain a model with an acceptable level of goodness of fit and to ensure its validity and reliability. After examining the multiple normality tests of the collected data, it was seen that the assumption of normality was not satisfied. Although Maximum Likelihood (ML), which is used for parameter estimates in SEM, produces relatively accurate estimates even in a dataset with non-normal distribution, it was observed that chi-square statistics and the standard errors of parameter estimates tend to be biased. For this reason, the Robust Maximum Likelihood (RML) method, which is recommended for the cases where the assumption of multiple normality cannot be achieved, was used to obtain the estimates. Because RML requires calculation of the asymptotic covariance matrix of variances and covariance's, LISREL 8.80, which can make this calculation, was used for measurement and structural model tests (Finney and DiStefano, 2006; Joreskog et al., 2016; Kline, 2015).

In the first application for the measurement model, confirmatory factor analysis results were examined and variables with factor loadings less than 0.50 were removed from the model as a result. The results of the 
goodness of fit $(\chi 2 / \mathrm{df}=588.36 ; \mathrm{RMSEA}=0.07 ; \mathrm{CFI}=$ $0.98 ; \mathrm{IFI}=0.98 ; \mathrm{NNFI}=0.98 ; \mathrm{RFI}=0.97)$ obtained from the analysis represent acceptable goodness of fit values (Schermelleh-Engel et al., 2003; Y1lmaz et al., 2008). Then, reliability and validity tests of the model were carried out.

Reliability is the stability of the independent measurements of a variable. Internal consistency, which is often used for reliability, measures how consistent and harmonious the answers, given to each question and the whole scale are. For this purpose, Cronbach's alpha coefficients are widely used. Cronbach's alpha coefficient value of over 0.70 indicates that the measurements are reliable. It is seen from Table 2 that the Cronbach's alpha values of structures are between 0.81 and 0.89 , and thus high internal consistency is provided. There are also reliability measures derived from CFA results. One of these is construct reliability, which is the internal consistency of the measurements of variables representing a latent construct. Equation (1) is used in the calculation of construct reliability. The value for construct reliability, should be more than 0.70 (Hair et al., 2014). As seen in Table 2, it is verified that all constructs are above this cut-off point and that the structures have high reliability.

$$
\text { Construct Reliability }=\frac{\sum(\mathrm{SPC})^{2}}{\sum(\mathrm{SPC})^{2}+\sum \varepsilon_{\mathrm{i}}}
$$

Validity is the quality of a scale to represents the same conceptual definition, have one dimension and requirements of reliability. In other words, validity means that the structure is measured without being mixed with other structures. The construct validity, used for this purpose, is the certitude that the observed variables can measure the latent structure, which they are expected to represent. Convergent reliability, as another criterion, is that indicators constituting a structure share a large measure of common variance. Discriminant validity is the certainty that the variables that make up a structure are separated from other structures and provide one dimensionality. To achieve construct validity, standardized path coefficients (SPC) should be more than 0.50. In order to achieve convergent and discriminant validity, it is sufficient that Average Variance Extracted (AVE) values of the structures are greater than 0.50. AVE is a measure of the convergence between the observed variables in a latent structure and is calculated by equation (2) (Hair et al., 2014; García et al., 2014).

$$
\mathrm{AVE}=\frac{\sum\left(\mathrm{SPC}^{2}\right)}{\sum\left(\mathrm{SPC}^{2}\right)+\sum \varepsilon_{\mathrm{i}}}
$$

As seen from Table 2, the structure shows that discriminant and convergent validity are satisfied due to all constructions having standardized path coefficients greater than 0.50 and AVE values greater than 0.50 . Once validity and reliability have been achieved, the structural model analysis is conducted.

\section{Structural model}

The structural model tests proposed hypothetical models. As a result of the analysis, the hypothetical model is acceptable $(\chi 2 / \mathrm{df}=1.61$, RMSEA $=0.05$, $\mathrm{SRMR}=0.06, \mathrm{CFI}=0.99, \mathrm{IFI}=0.99, \mathrm{NNFI}=0.99, \mathrm{RFI}$ $=0.98$ ). The path coefficients of relationships in the hypothetical model are given in Figure 2.

According to the results of SEM, system quality $(\beta=.15, \mathrm{t}=2.09)$, trust $(\beta=.30, \mathrm{t}=2.30)$, satisfaction $(\beta=.56, \mathrm{t}=2.91)$ and word of mouth $(\beta=.58, \mathrm{t}=5.34)$ positively affect e-loyalty. On the other hand, alternative attractiveness has a negative effect on eloyalty $(\beta=-.09, \mathrm{t}=-3.14)$. Among these constructs, word of mouth appears to be more influential on eloyalty. Moreover, the influence of e-loyalty on repurchase intention was also confirmed $(\beta=.96$, $\mathrm{t}=10.20$ ). Therefore, because all $\mathrm{t}$-values of the relations are bigger than 1.96 or less than -1.96 , all hypotheses in the hypothetical model were accepted. With regard to the results obtained, it can be said that e-loyalty has a mediator role in the relationship system quality, trust, satisfaction, alternative attractiveness, word of mouth and repurchase intention.

Following the hypothetical model with significant and well-fitted values, we sought to find alternative models including different relationships that can be formed with the same variables. Alternative models (A, B, C, D and E) which involved in different significant relations were generated and the fit indices related to these models are given in Table 3. 
Table 2. Results of measurement model

\begin{tabular}{|c|c|c|c|c|c|c|c|}
\hline Construct and Items & Mean & Std.D & $\begin{array}{l}\text { Std. factor } \\
\text { Loads }\end{array}$ & $\begin{array}{c}\mathrm{t} \\
\text { Value }\end{array}$ & $\mathrm{CR}$ & AVE & $\begin{array}{l}\text { Cronbach's } \\
\text { alpha }\end{array}$ \\
\hline System Quality & & & & & 0.85 & 0.54 & 0.85 \\
\hline $\begin{array}{l}\text { A customer who buys a travel for the first time on this website } \\
\text { may complete the transaction without assistance. }\end{array}$ & 5.76 & 1.12 & 0.73 & 9.12 & & & \\
\hline This website is a user-friendly website. & 5,71 & 1.04 & 0.87 & 12.43 & & & \\
\hline $\begin{array}{l}\text { This website has a search tool that enables me to locate } \\
\text { products. }\end{array}$ & 6.04 & 0.99 & 0.66 & 6.61 & & & \\
\hline The information on the website is well organized. & 5.85 & 1.18 & 0.71 & 8.52 & & & \\
\hline The website's layout and colours are appealing. & 5.71 & 1.22 & 0.70 & 8.52 & & & \\
\hline Trust & & & & & 0.89 & 0.68 & 0.89 \\
\hline $\begin{array}{l}\text { I trust in the benefits of options such as suggestions and offers } \\
\text { offered on this website. }\end{array}$ & 5.55 & 1.10 & 0.70 & 9.32 & & & \\
\hline This website keeps its promises and commitments. & 5.84 & 1.09 & 0.85 & 10.22 & & & \\
\hline This website protects the interests of customers. & 5.49 & 1.19 & 0.81 & 12.83 & & & \\
\hline I trust in this website. & 5.84 & 0.98 & 0.93 & 10.57 & & & \\
\hline Satisfaction & & & & & 0.92 & 0.80 & 0.82 \\
\hline I am satisfied with my decision to purchase from this website. & 5.98 & 0.91 & 0.87 & 8.88 & & & \\
\hline $\begin{array}{l}\text { If I had to purchase again, I would feel differently about } \\
\text { buying from this website. }\end{array}$ & 5.72 & 1.00 & 0.91 & 11.31 & & & \\
\hline I think I did the right thing by buying from this website. & 5.71 & 1.04 & 0.90 & 10.95 & & & \\
\hline Alternatives Attractiveness & & & & & 0.83 & 0.63 & 0.81 \\
\hline $\begin{array}{l}\text { If I need to change this website, I have some good travel } \\
\text { reservation websites that I can use instead. }\end{array}$ & 4.98 & 1.36 & 0.80 & 12.39 & & & \\
\hline $\begin{array}{l}\text { Compared to this website, there are other websites with which } \\
\text { I would probably be equally or more satisfied. }\end{array}$ & 4.64 & 1.44 & 0.98 & 20.39 & & & \\
\hline Other websites would benefit me more than this website. & 3.68 & 1.34 & 0.55 & 9.48 & & & \\
\hline Word of Mouth & & & & & 0.85 & 0.71 & 0.85 \\
\hline I say positive things about this website to other people. & 5.75 & 1.06 & 0.94 & 12.13 & & & \\
\hline I recommend this website to anyone who seeks my advice. & 5.66 & 1.18 & 0.94 & 13.76 & & & \\
\hline I hesitate to refer my acquaintances to this website. & 2.29 & 1.11 & 0.61 & 6.50 & & & \\
\hline E-loyalty & & & & & 0.93 & 0.76 & 0.83 \\
\hline I try to use the website whenever I need to make a purchase. & 5.75 & 1.33 & 0.86 & 11.85 & & & \\
\hline $\begin{array}{l}\text { When I need to make a travel purchase, this website is my } \\
\text { first choice. }\end{array}$ & 5.79 & 1.22 & 0.83 & 12.00 & & & \\
\hline I like to use this website. & 5.76 & 1.04 & 0.87 & 11.31 & & & \\
\hline $\begin{array}{l}\text { In my opinion, this website is the best website for buying a } \\
\text { travel. }\end{array}$ & 5.25 & 1.14 & 0.82 & 13.97 & & & \\
\hline I believe that this is my favourite travel reservation website. & 5.55 & 1.15 & 0.91 & 14.89 & & & \\
\hline Repurchase Intention & & & & & 0.90 & 0.74 & 0.89 \\
\hline $\begin{array}{l}\text { I will make my next travel reservation from the same website } \\
\text { again. }\end{array}$ & 5.46 & 1.12 & 0.75 & 12.05 & & & \\
\hline $\begin{array}{l}\text { Soon, I will consider my current supplier as part of my evoked } \\
\text { set. }\end{array}$ & 5.77 & 1.01 & 0.90 & 11.48 & & & \\
\hline $\begin{array}{l}\text { I would like to continue the purchasing relationship with this } \\
\text { website. }\end{array}$ & 5.77 & 1.06 & 0.93 & 13.05 & & & \\
\hline
\end{tabular}


Figure 2. Result of structural model test for the hypothetical model.

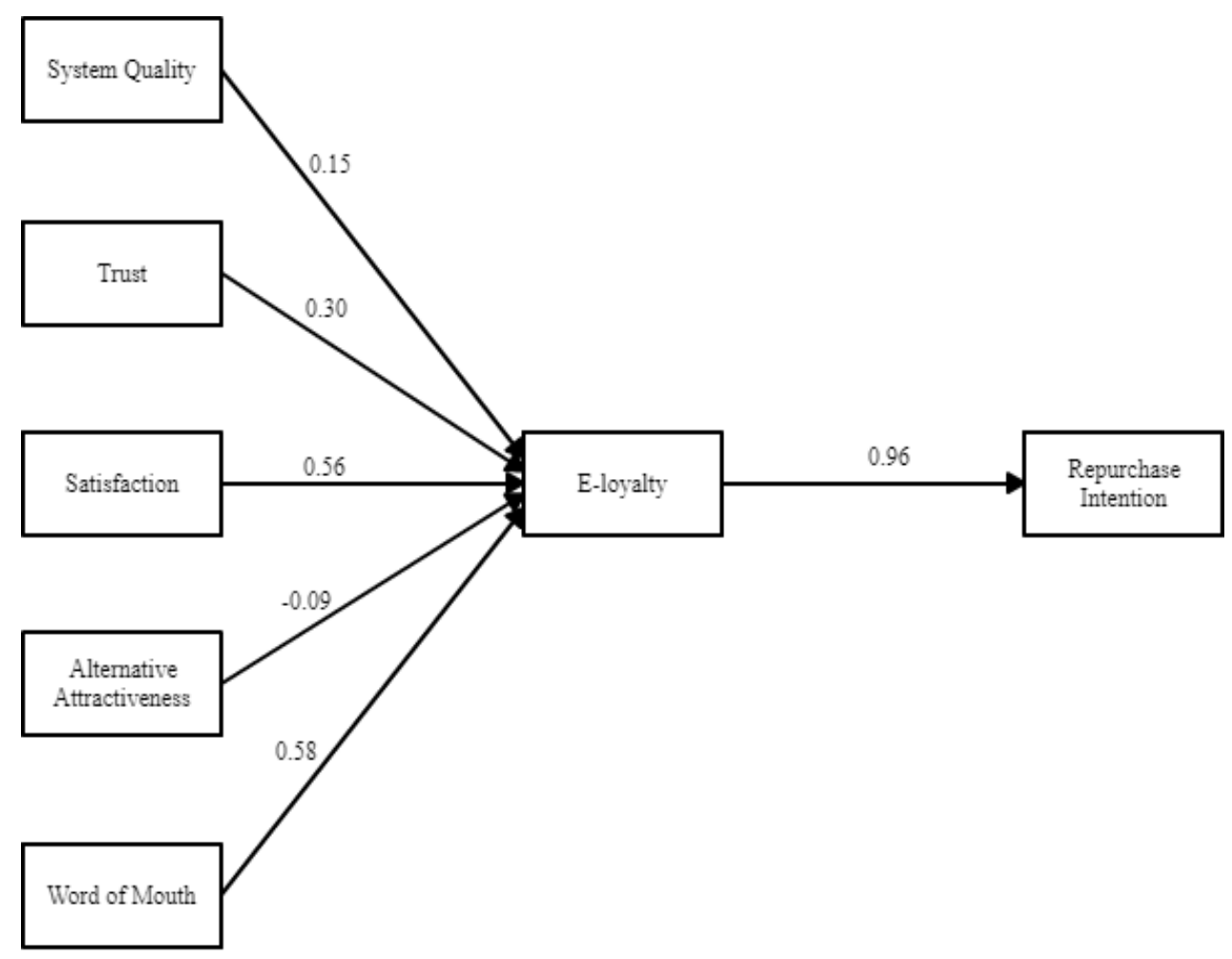

Hypothetical Model

Note: All path coefficients are significant at p .05 or lower degree.

Table 3. Goodness of fit test results of alternative models

\begin{tabular}{llllllllll}
\hline Model & $\chi^{2}$ & $\mathrm{df}$ & $\chi^{2} / \mathrm{df}$ & RMSEA & SRMR & CFI & IFI & NNFI & RFI \\
\hline Hypothetical & 456.09 & 283 & 1.61 & 0.047 & 0.061 & 0.99 & 0.99 & 0.99 & 0.98 \\
A & 417.16 & 282 & 1.48 & 0.041 & 0.060 & 0.99 & 0.99 & 0.99 & 0.98 \\
B & 467.65 & 286 & 1.64 & 0.047 & 0.063 & 0.99 & 0.99 & 0.99 & 0.98 \\
C & 427.56 & 285 & 1.50 & 0.041 & 0.062 & 0.99 & 0.99 & 0.99 & 0.98 \\
D & 417.12 & 282 & 1.47 & 0.040 & 0.060 & 0.99 & 0.99 & 0.99 & 0.98 \\
E & 468.78 & 287 & 1.63 & 0.047 & 0.060 & 0.99 & 0.99 & 0.99 & 0.98 \\
\hline Criteria & & & 3 & $<0.10$ & $<0.10$ & $>0.90$ & $>0.90$ & $>0.90$ & $>0.90$ \\
\hline
\end{tabular}

Alternative models with the valid goodness of fit values are shown in Fig 3. In Model A, as distinct from the hypothetical model, it is seen that there is a relationship between satisfaction and repurchase intention $(\beta=.49, \mathrm{t}=4.41)$. This relationship means that the increase in customer satisfaction has the potential to increase repurchase intention. This result is in agreement with the conclusion found by Eggert and Ulaga's (2002) study. In addition, Model A has acceptable goodness of fit values $(\chi 2 / \mathrm{df}=1.48$, RMSEA $=0.04$, SRMR $=0.06, \mathrm{CFI}=0.99, \mathrm{IFI}=0.99$, $\mathrm{NNFI}=0.99, \mathrm{RFI}=0.98$ ). 
Figure 3. Alternative models.
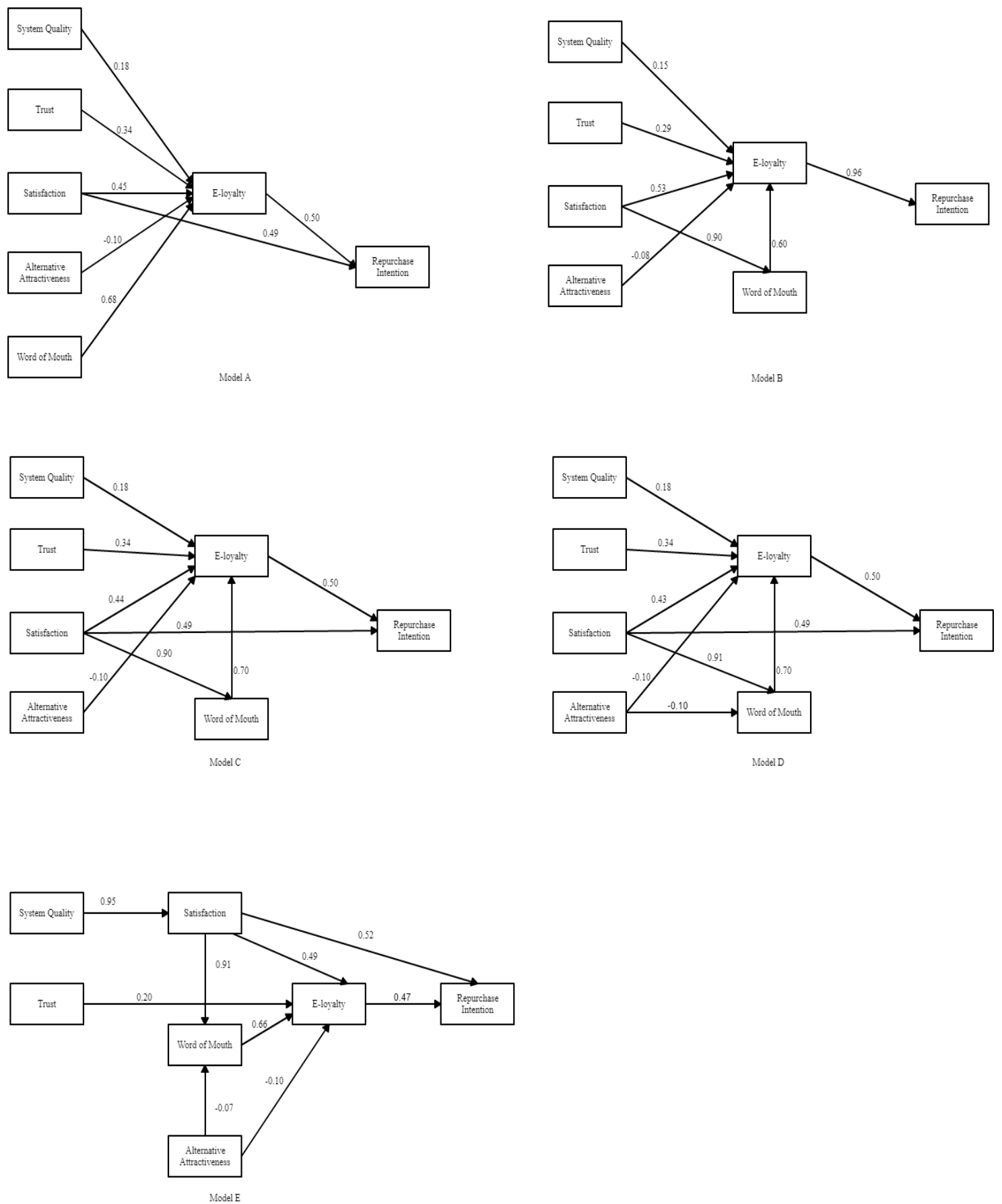

Note: All path coefficents are significant at p .05 or lower degree.

In Model B, the path that satisfaction has a positive effect on word of mouth found to be seen significant ( $\beta=.90, t=10.56)$. The path coefficient of 0.90 between the two structures indicates that satisfaction increases the positive recognition of the enterprise by word of mouth. Table 3 shows that Model B is also an acceptable model $(\chi 2 / \mathrm{df}=1.64$, RMSEA $=0.04$, SRMR $=0.06, \mathrm{CFI}=0.99, \mathrm{IFI}=0.99, \mathrm{NNFI}=0.99, \mathrm{RFI}=$ 0.98). Extant literature also confirms the existence of a relationship between satisfaction and word of mouth (E. W. Anderson, 1998; Maxham and Netemeyer, 2002).

Model $\mathrm{C}$ was obtained by simultaneously adding two paths, which indicate that satisfaction has influence on word of mouth $(\beta=.90, t=10.57)$ and repurchase intention $(\beta=.49, \mathrm{t}=4.11)$, to the hypothetical model. The values of goodness of fit indicate that the model is valid $(\chi 2 / \mathrm{sd}=1.50$, 
RMSEA $=0.04$, SRMR $=0.06$, CFI $=0.99$, IFI $=0.99$, $\mathrm{NNFI}=0.99, \mathrm{RFI}=0.98)$. Accordingly, e-loyalty was found to partially mediate the influence of of satisfaction on repurchase intention full mediating variable role for word of mouth.

With model $\mathrm{D}$, the path in which alternative attractiveness has negative effect on word of mouth was added $(\beta=-.10, \mathrm{t}=-2.75)$. This path has a standardized path coefficient value of -0.10 . The belief by the customers that there are alternatives that can offer service of the same quality as the current ecommerce website may be expected to negatively affect word of mouth. It is seen from Table 3 that Model D confirming this relationship is sufficient in terms of goodness of fit indices $(\chi 2 / \mathrm{df}=1.47$, RMSEA $=0.04$, SRMR $=0.06$, CFI $=0.99$, IFI $=0.99$, NNFI $=0.99$, RFI $=0.98)$. Accordingly, the attractiveness of one or more alternatives reduces the positive word of mouth of the customer about the ecommerce website.

Finally, Model E presented that satisfaction is a mediator variable between system quality $(\beta=.95$, $\mathrm{t}=8.34)$ and e-loyalty $(\beta=.49, \mathrm{t}=3,65)$. It is seen from Table 3 that the model is valid $(\chi 2 / \mathrm{df}=1.63$, RMSEA $=0.05$, SRMR $=0.06, \mathrm{CFI}=0.99, \mathrm{IFI}=0.99$, $\mathrm{NNFI}=0.99, \mathrm{RFI}=0.98)$. This result is in line with the study conducted by Ko et al. (2011) that the system quality has a positive effect on the satisfaction of the customers and satisfaction has the mediating relationship between system quality and e-loyalty.

\section{Conclusions and implications}

This study set out to develop an e-loyalty model for travel reservation websites. The results showed that system quality, trust, satisfaction and word of mouth have a positive effect on e-loyalty, while alternative attractiveness affects e-loyalty negatively. E-loyalty was also found to have a positive effect on repurchase intention. Within the scope of the alternative modelling strategy adopted in the study, five different models were also found to be agreeable with data and literature. Although the goodness of fit values of all models are close to each other, model D in which satisfaction positively affects word of mouth and repurchase intention, and alternative attractiveness has a negative effect on word of mouth is the best suited model differently the hypothetical model. When all the models are evaluated together it can be seen that; enhancing the quality of travel reservation websites could increase the levels of satisfaction and e-loyalty of the customers; satisfaction positively affects word of mouth, e-loyalty and repurchase intention; and that the trust of the customers on the website increases eloyalty. On the other hand, the increase in alternative attractiveness has a negative effect on word of mouth and e-loyalty. While word of mouth is positively affected by satisfaction, and negatively influenced by alternative attractiveness, it positively affects eloyalty. It can thus be concluded that customers repurchase intention increases when they have high eloyalty and satisfaction.

The results of the study are thought to have some important implications for travel reservation websites. Having satisfied and e-loyal customers determines the distinction of a website among competitors. In this framework, websites should pay utmost attention to regulations that enhance customer satisfaction. The system quality, trust and word of mouth, all of which affect e-loyalty, should be evaluated carefully. Studies indicate that websites for travel reservations that are well designed it terms of organization of information, ease of navigation so customers can easily find what they are looking for, and layouts that pique customers' interests, generally have increased customer satisfaction and e-loyalty. The extent of trust customers has on the website also increases their eloyalty. In this regard, the websites must thus fulfil their commitments diligently, giving importance to the privacy of the customers and not bothering them with unnecessary suggestions and advertisements. Xiaojuan Ou and Ling Sia (2003) noted that positive word of mouth is more effective than advertising, email, and many other marketing techniques. Businesses should include systems that enhance customer satisfaction to ensure positive word of mouth, which engages the customers volunteer advertisers and sponsors of the business. Being e-loyalty and satisfied customers to travel reservation websites provides to use the same website for future purchases. As long as this e-loyalty continues, the client tends to maintain the travel purchase relationship on the same website.

There are some limitations to this study. Firstly, the study was applied to academicians. For this reason, it is not possible to generalize the results to include other occupational groups. Moreover, since it was carried 
out in Turkey, the same results should not be expected for other countries. Differences may be observed on eloyalty related factors depending on legal, cultural, sectoral and technological developments. Future studies should consider these differences. More generalized results could be obtained with crosscountry studies that consider multiple occupations. The model developed in this study could developed along the proposed structures.

Footnote: 1. http://www.turizmajansi.com/haber/eticarette-site-sayisi-azaliyor-pazar-buyuyor-h6794.

Access date: 16.06.2017.

\section{Reference}

Akbulut, Y. (2014). Exploration of the antecedents of digital piracy through a structural

equation model. Computers \& Education, 78, 294-305. doi:10.1016/j.compedu.2014.06.016

Anderson, E. W. (1998). Customer satisfaction and word of mouth. Journal of Service Research. doi:10.1177/109467059800100102

Anderson, R. E., \& Srinivasan, S. S. (2003). E-satisfaction and e-Loyalty: A contingency framework. Psychology and Marketing, 20(2), 123-138. doi:10.1002/mar.10063

Balabanis, G., Reynolds, N., \& Simintiras, A. (2006). Bases of e-store loyalty: Perceived switching barriers and satisfaction. Journal of Business Research, 59(2), 214224. doi:10.1016/j.jbusres.2005.06.001

Chen, J. V., Yen, D. C., Pornpriphet, W., \& Widjaja, A. E. (2015). E-commerce web site loyalty: A cross cultural comparison. Information Systems Frontiers, 17(6), 1283-1299. doi:10.1007/s10796-014-9499-0

Curtis, T., Abratt, R., Dion, P., \& Rhoades, D. (2011). Customer satisfaction, loyalty and repurchase: Some evidence from apparel consumers. Review of Business, $32(1), 47-58$.

Curtis, T., Abratt, R., Rhoades, D., \& Dion, P. (2011). Customer loyalty, repurchase and satisfaction: A metaanalyctical review. Journal of Consumer Satisfaction, Dissatisfaction \& Complaining Behavior, 24, 1-26.

DeLone, W., \& McLean, E. R. (1992). Information systems success: The quest for the dependent variable. Information Systems Research, 3(1), 60-95. doi:/10.1287/isre.3.1.60

DeLone, W., \& McLean, E. (2004). Measuring e-commerce success: Applying the DeLone \& McLean Information Systems Success Model. International Journal of
Electronic Commerce, 9(1), 31-47. doi:10.1080/10864415.2004.11044317

Ecommerce Foundation. (2016). Global B2C e-commerce report.

https://www.ecommercewiki.org/wikis/www.ecommerc ewiki.org/images/5/56/Global_B2C_Ecommerce_Repo rt_2016.pdf

Eggert, A., \& Ulaga, W. (2002). Customer perceived value: a substitute for satisfaction in business markets? Journal of Business \& Industrial Marketing, 17(2/3), 107-118. doi: $10.1108 / 08858620210419754$

Finney, S. J., \& DiStefano, C. (2006). Non-normal and categorical data in structural equation modeling. Structural equation modeling: A second course, 269-314

Floh, A., \& Treiblmaier, H. (2006). What keeps the ebanking customer loyal? A multigroup analysis of the moderating role of consumer characteristics on e-loyalty in the financial service industry. SSRN Electronic Journal. doi:10.2139/ssrn.2585491

García, J. L., Maldonado, A. A., Alvarado, A., \& Rivera, D. G. (2014). Human critical success factors for kaizen and its impacts in industrial performance. International Journal of Advanced Manufacturing Technology, 70(912), 2187-2198. doi:10.1007/s00170-013-5445-4

Gommans, M., Krishnan, K. S., \& Scheffold, K. B. (2001). From brand loyalty to e-loyalty: A conceptual framework. Journal of Economic and Social Research, 3(1), 43-58. doi:10.1177/014920639702300305

Griffin, J., \& Herres, R. T. (2002). Customer loyalty: How to earn it, how to keep it. San Francisco, CA: JosseyBass.

Hair, J. F., Black, W. C., Babin, B. J., \& Anderson, R. E. (2014). Multivariate data analysis (7th ed.). Edinburgh Gate, Harlow: Pearson Education Limited.

Hellier, P. K., Geursen, G. M., Carr, R. A., \& Rickard, J. A. (2003) "Customer repurchase intention: A general structural equation model", European Journal of Marketing, Vol. 37 Issue: 11/12, pp.1762-1800, https://doi.org/10.1108/03090560310495456

Huang, L. (2008). Exploring the determinants of e-loyalty among travel agencies. The Service Industries Journal, 28(2), 239-254. doi:10.1080/02642060701842316

Joreskog, K. G., Olsson, U. H., \& Wallentin, F. Y. (2016). Multivariate analysis with LISREL. Springer.

Kim, J., Jin, B., \& Swinney, J. L. (2009). The role of etail quality, e-satisfaction and e-trust in online loyalty development process. Journal of Retailing and 
Consumer Services, 16(4), 239-247. doi:10.1016/j.jretconser.2008.11.019

Kline, R. B. (2015). Principles and practice of structural equation modeling (4th ed.). Guilford Publications.

Ko, Y. J., Hur, Y., \& Valacich, J. (2011). A structural model of the relationships between sport website quality, esatisfaction, and e-loyalty. Journal of Sport Management, 25(5), 458-473.

Kuan, H.H., Bock, G.-W., \& Vathanophas, V. (2005). Comparing the effects of usability on customer conversion and retention at e-commerce websites. Proceedings of the 38th Annual Hawaii International Conference on System Sciences, 0(C), 1-9. doi:10.1109/HICSS.2005.155

Litvin, S. W., Goldsmith, R. E., \& Pan, B. (2008). Electronic word-of-mouth in hospitality and tourism management. Tourism Management, 29(3), 458-468. doi:10.1016/j.tourman.2007.05.011

Maxham, J. G., \& Netemeyer, R. G. (2002). Modelling customer perceptions of complaints handling over time: the effect of perceived justice on satisfaction and intent. Journal of Retailing, 78, 239-252. doi:10.1016/S00224359(02)00100-8

Muthén, L. K., \& Muthén, B. O. (2002). How to use a monte carlo study to decide on sample size and determine power. Structural Equation Modeling: A Multidisciplinary Journal, 9(4), 599-620, doi:10.1207/S15328007SEM0904_8

Nusair, K., \& Hua, N. (2010). Comparative assessment of structural equation modeling and multiple regression research methodologies: E-commerce context. Tourism Management, 31(3), 314-324. doi:10.1016/j.tourman.2009.03.010

Oliver, R. (1999). Whence consumer loyalty? Journal of Marketing, 63, 33-44. doi:10.2307/1252099

Ping, R. A. (1993). The effects of satisfaction and structural constraints on retailer exiting, voice, loyalty, opportunism, and neglect. Journal of Retailing, 69(3), 320-352.

Reichheld, F. F., \& Schefter, P. (2000). E-Loyalty: Your secret weapon on the web. Harvard Business Review, 78(4), 105-113. doi:10.1007/PL00012187

Ribbink, D., van Riel, A. C. R., Liljander, V., \& Streukens, S. (2004). Comfort your online customer: Quality, trust and loyalty on the Internet. Managing Service Quality: An International Journal, 14(6), 446-456. doi:10.1108/09604520410569784

Rusbult, C. E. (1980). Commitment and satisfaction in romantic associations: A test of the investment model. Journal of Experimental Social Psychology, 16(2), 172186. doi:10.1016/0022-1031(80)90007-4

Schermelleh-Engel, K., Moosbrugger, H., \& Müller, H. (2003). Evaluating the fit of structural equation models: Tests of significance and descriptive goodness-of-fit measures. Methods of Psychological Research Online, 8(2), 23-74. doi:10.1002/0470010940

Srinivasan, S. S., Anderson, R., \& Ponnavolu, K. (2002). Customer loyalty in e-commerce: An exploration of its antecedents and consequences. Journal of Retailing, 78(1), 41-50. doi:10.1016/S0022-4359(01)00065-3

Şimşek, Ö. F. (2007). Yapısal eşitlik modellemesine giriş: Temel ilkeler ve LISREL uygulamaları. Ankara: Ekinoks.

Toufaily, E., Ricard, L., \& Perrien, J. (2013). Customer loyalty to a commercial website: Descriptive metaanalysis of the empirical literature and proposal of an integrative model. Journal of Business Research, 66(9), 1436-1447. doi:10.1016/j.jbusres.2012.05.011

Valvi, A. C., \& Fragkos, K. C. (2012). Critical review of the e-loyalty literature: A purchase-centred framework. Electronic Commerce Research. doi:10.1007/s10660012-9097-5

Werthner, H., \& Ricci, F. (2007). E-commerce and Tourism. Communications of the ACM, 47(12), 101-105.

Wu, L. (2011). Satisfaction, inertia, and customer loyalty in the varying levels of the zone of tolerance and alternative attractiveness. Journal of Services Marketing, 25(5), 310-322. doi:10.1108/08876041111149676

Xiaojuan Ou, C., \& Ling Sia, C. (2003). Customer loyalty strategy in the Internet era. 7th Pacific Asia Conference on Information Systems, (July), 1734-1744.

Yılmaz, V., Çatalbaş, G. K., \& Çelik, E. (2008). Yapısal eşitlik modellemesi ile algilanan değer, memnuniyet ve sadakat arasindaki ilişkinin araştirilmasi: Kredi kartı kullanımı üzerine bir uygulama. Bankacilar Dergisi, (64), 27-38. 